\title{
Research on the Mathematical Model of Local Equilibrium in the Top-Blown Smelting Process of Electronic Waste
}

\author{
Xiaochun Wen ${ }^{1,2} \mathbb{D}^{\text {, Jinliang Wang }}{ }^{1,2, *}$ and Houqing Wang ${ }^{1,2}$ \\ 1 Jiangxi Provincial Key Laboratory of Flash Green Development and Recycling, \\ Jiangxi University of Science and Technology, Ganzhou 341000, China; 9120210002@jxust.edu.cn (X.W.); \\ 7120180013@mail.jxust.edu.cn (H.W.) \\ 2 Faculty of Materials Metallurgy and Chemistry, Jiangxi University of Science and Technology, \\ Ganzhou 341000, China \\ * Correspondence: wangil@jxust.edu.cn; Tel.: +86-139-7014-8589
}

check for updates

Citation: Wen, X.; Wang, J.; Wang, H. Research on the Mathematical Model of Local Equilibrium in the Top-Blown Smelting Process of Electronic Waste. Metals 2021, 11, 1500. https://doi.org/10.3390/ met11101500

Academic Editor: Leszek Blacha

Received: 4 August 2021

Accepted: 18 September 2021

Published: 22 September 2021

Publisher's Note: MDPI stays neutral with regard to jurisdictional claims in published maps and institutional affiliations.

Copyright: (c) 2021 by the authors. Licensee MDPI, Basel, Switzerland. This article is an open access article distributed under the terms and conditions of the Creative Commons Attribution (CC BY) license (https:/ / creativecommons.org/licenses/by/ $4.0 /)$.

\begin{abstract}
In the present study, the local equilibrium modeling and division method of the multiphase non-equilibrium for the top-blowing smelting process of electronic waste was investigated based on the local equilibrium hypothesis. And the mathematical description of the multi-phase equilibrium of each local area and the correlation method between the local areas were studied by analysis of relationships among the valence state, phase, composition, and Gibbs free energy of each element. Afterward, the reaction characteristic data such as melting material, product phase, composition, temperature, atmosphere, etc. were obtained via industrial measurement experiments. Based on these, a mathematical model of local equilibrium for the top-blowing smelting process of electronic waste was established. Finally, the thermodynamic digital simulation system was developed via the calculation of metallurgical process and online control platform MetCal Desk (v7.00, MetCal, Ganzhou, China), which can investigate the element distribution behavior during the smelting process and provide theoretical guidance for the industrial production practice.
\end{abstract}

Keywords: local equilibrium; mathematical model; top-blown smelting; simulation system; electronic waste

\section{Introduction}

With continuous improvements in science and technology, the electronics industry has ushered in rapid changes. The number of eliminated electronics-related products is increasing rapidly due to the short replacement cycle of electronic products [1-4]. Currently, 20-50 million tons of e-waste are generated globally, and the average annual growth rate is three times that of other solid wastes according to an analysis report by the United Nations Environment Programme [5,6]. In addition, e-waste is increasing at an annual growth rate of $3 \%$ to $5 \%$ in EU countries, which will also increase more than three times in developing countries over the next five years [7]. These will not only cause huge environmental pressure, but also provide broad prospects for the utilization of valuable resources; the economic value and environmental benefits have also become increasingly prominent.

Since the 1970s, a variety of new technologies and equipment for the comprehensive utilization of rare and precious metal renewable resources have been developed, which use anode slime, electronic waste, and industrial slag containing rare and precious metals as raw materials [2,8]. For instance, Bydałek. A. et al. [9] reported a novel method of separating some metals from liquid slag; the structure of the slag in liquid state, the properties and interactions within the slag were discussed in detail. Furthermore, there are many valuable metals and organic substances in electronic waste, and its recycling and utilization can not only solve the problem of environmental pollution but also recover valuable secondary resources.

In recent years, the comprehensive recycling technology of electronic waste has become a hot topic globally and a wide variety of novel processes can be developed [10-13]. 
For instance, the United States uses Kaldor furnaces to smelt electronic waste, Germany and Belgium use ISA furnaces, and Japan and South Korea use Ausmelt furnaces. For China, after simple physical separation of electronic scrap, most of the rare and precious metals are enriched in the crude copper during the smelting process, realizing the separation from non-metals. Afterward, the crude copper is refined by the pyrorefining process, and then rare precious metals are recovered from the electrolytic anode slime. Nevertheless, there are lots of problems in the electrolysis process, such as serious depletion of copper ions, high cell voltage, and low current efficiency in terms of low copper grade and high impurities in crude copper [14-16]. Moreover, the existing process of copper anode slime has defects such as long process, difficult comprehensive recovery of precious metals, temperature distribution asymmetry, incomplete low-temperature cracking of organic matter, dioxins in tail gas [17], etc. Therefore, it can be seen that the overall treatment technology and equipment of electronic waste need to be further improved and innovated.

In view of these, the Nerin Recycling Technology (NRT), an innovative comprehensive recycling process for electronic waste, was developed and took the lead in realizing industrial applications. Similar to the Kaldor furnace, ISA furnace, and Ausmelt furnace, the NRT furnace is a high-temperature intensified top-blown bath smelting furnace, which has broad prospects for popularization and application. However, how to improve the direct recovery of valuable metals and reduce the emission of toxic and harmful gases is a key issue to realize efficient smelting and clean production of electronic waste.

The slag-gold-gas system has characteristics of great heat and mass transfer conditions and a high reaction rate due to the high-pressure swirling effect produced by the hydrocyclone based on the research of top-blowing submerged bath smelting [18]. It can be seen that the electronic waste reacts quickly with the gas by the continuous injection of excess oxygen during the process of high-temperature molten pool smelting, which indicates good reaction kinetic conditions. At the same time, the high-temperature smelting reaction system involves different phases such as blister copper, copper matte, slag, magnetite, and flue gas. The composition of electronic waste, smelting temperature, and reaction atmosphere are constantly changing in the process of high-temperature smelting for several hours. The reaction system has obvious non-equilibrium multiphase reaction characteristics because of the continuous phase transformation and component migration, and then gradually completes complex reactions such as oxidation, combustion, slagging, copper production, etc.

It is difficult to comprehensively analyze the physical and chemical behavior of electronic waste during the smelting process in the laboratory due to the complexity of the high-temperature non-equilibrium reaction system. To solve this problem, the predecessors have made many successful explorations, carrying out the experimental research directly in an industrial furnace $[19,20]$. Wołczyński. W. et al. [21] investigated copper droplets agglomeration/coagulation in conditions that were similar to those usually applied to the industrial process, and the influence of the liquid slag stirring on the copper droplets self-cleaning was also analysed. However, the production practice usually requires relatively stable process conditions, which makes it difficult to implement a large number of experiments in the factory. Thus, it is necessary to find a method to investigate the influence of various working situations on the physicochemical behavior of electronic waste in the smelting process.

Nowadays, digital-analog simulation technology has become an effective method for studying the laws of high-temperature pyrometallurgy with the rapid development of computer technology. For example, Wang [22], Xu [23], Zhang [24], Li [25], and the author of this work [26] performed thermodynamic computer simulations on high-temperature molten pool smelting. It can be found that they all regard the entire smelting furnace as a closed system reaching or approaching the equilibrium of chemical reactions. Besides, the smelting furnace is regarded as a "black box", which cannot reflect the microscopic migration and transformation behavior of materials during the smelting process. 
The local-equilibrium hypothesis is an important method for solving non-equilibrium thermodynamics problems by classical thermodynamics and has been successfully applied to some fields such as metallurgy and materials. Previous studies on the melting kinetics of top-blowing immersed bath smelting provide a feasible theoretical basis for introducing the local equilibrium assumption into the modeling of a non-equilibrium multiphase system in top-blowing smelting of electronic waste. Hence, the high-temperature molten pool smelting process is regarded as a multi-phase reaction system in which electronic waste and reaction gas continuously reach a local equilibrium, and the time is discrete in millisecond order. Simultaneously, the smelting process is divided into several microelement localities of time, and then a multi-phase equilibrium mathematical model is constructed for each time microelement region according to the principle of minimum Gibbs free energy. Afterward, the local models are associated based on the transfer relationship between electronic waste and reaction gas in each micro-element local area; in this way, the mathematical model of the composition transfer and transformation of electronic waste in the smelting process is established, and the non-equilibrium multiphase reaction system of the electronic waste smelting is also analyzed.

In conclusion, based on the local equilibrium hypothesis of the non-equilibrium system and combined with the production practice of the NRT smelting industry, the local equilibrium modeling and division method of the non-equilibrium multiphase reaction system of the electronic waste top-blowing smelting process are investigated in this study. The mathematical description of the multi-phase equilibrium of each local area and the correlation method between the local areas are studied on the basis of the analysis of the relationship between valence state, phase, composition, and Gibbs free energy of each element. In addition, reaction characteristic data such as melting material, product phase, composition, temperature, atmosphere, etc. are obtained by industrial measurement experiments. It can provide production practice data for the construction, verification, and optimization of digital models, which will help to further improve the consistency between the model and production practice. Furthermore, the establishment of a local equilibrium mathematical model for the top-blowing smelting process of electronic waste can provide theoretical guidance for the development of a thermodynamic digital simulation system.

\section{Top-Blowing Smelting System of Electronic Waste}

Figure 1 depicts the flow chart of the top-blowing smelting system of electronic waste. It can be seen that the smelting system mainly consists of a feeder, furnace stack, combustion chamber, waste heat boiler, and discharge outlet. The top-blowing melting process is as follows: firstly, the crushed electronic waste, slagging flux, and additives (iron powder) are put into the high-temperature furnace together with air. Secondly, refractory oxides such as plastics and glass fibers are burned and removed from the molten pool in the form of high-temperature flue gas. The heat in the furnace is ensured by exothermic reactions from the burden. Then the impurity metal is oxidized to form the slag phase with slagging flux, at the same time, the copper and precious metals such as gold, silver, platinum, and palladium form a molten metal phase. Finally, the metal phase and the slag phase are stratified due to the difference in immiscibility and density. Based on this, the main purpose of top-blowing smelting of electronic waste is to separate metals and non-metals, while enriching rare and precious metals such as gold, silver, platinum, and palladium in the crude copper as much as possible. 


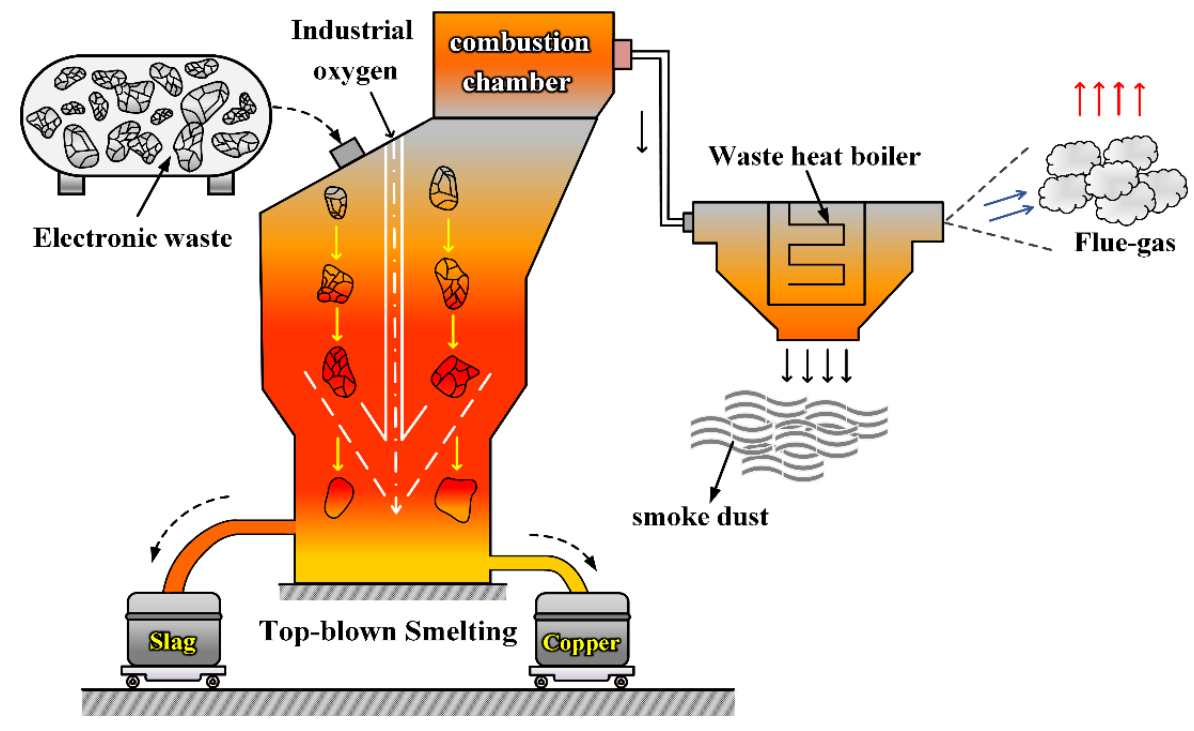

Figure 1. Flow chart of the top-blowing smelting system of electronic waste.

Generally, the thermodynamic equilibrium state is the stationary state of the zerodegree due to the thermodynamics of irreversible processes, and the course of the stationary process at the entropy production minimum was justified [27].

In this work, as the heat and mass transfer process in the slag-gold-gas system can be strengthened in the top-blowing submerged bath smelting, the composition of electronic waste, smelting temperature, and reaction atmosphere have typical characteristics of non-equilibrium heterogeneous reaction. Thus, the local equilibrium assumption can be introduced in this non-equilibrium system, and then a local equilibrium mathematical model for the top-blowing smelting process of electronic waste will be established.

\subsection{Modeling Method of Local Equilibrium}

The local-equilibrium hypothesis plays an important role in solving non-equilibrium thermodynamics issues based on the classical thermodynamic theory. It has been successfully applied to metallurgy, materials, and other fields. Koshikawa [28] effectively simulated the phase transformation behavior in the solidification process of metal alloy by introducing the local equilibrium assumption. Similarly, Zhang [29] carried out a local equilibrium thermodynamic calculation on the solidification process of cast iron and successfully predicted the phenomenon of carbide deposition. Furthermore, Wang [30] established the local equilibrium mathematical model of the reaction shaft in a copper flash smelting furnace and investigated the formation thermodynamics of $\mathrm{Fe}_{3} \mathrm{O}_{4}$ in the reaction tower, the results of which are consistent with the measured values in the literature.

The top-blowing smelting process of electronic waste has characteristics of uniform mixing of raw materials and gas, and rapid reaction, that is, in a very short time (such as $1 \mathrm{~ms}$ ), it can be considered to reach or be close to an equilibrium state. In view of these, the molten pool smelting process is regarded as a multi-phase reaction system in which electronic waste and reaction gas continuously reach local equilibrium. Meanwhile, by introducing the local equilibrium assumption of a non-equilibrium system, the entire smelting process can be divided into several time micro-element regions, and the multiphase equilibrium mathematical model can be constructed according to the principle of minimum Gibbs free energy. To establish a mathematical model for the migration and transformation of electronic waste components in the smelting process, it is necessary to associate electronic waste and reactive gas in each micro-element local model. 


\subsection{Physical Model Description}

In this study, for the stabilization process of top-blowing smelting with a certain scale of electronic waste treatment, assuming that the entire smelting process is divided into $n$ local regions with the same reaction time of $1 \mathrm{~ms}$ when burning and melting inhomogeneous and heterogeneous burden, the electronic waste and the reaction gas can be considered to reach or be close to the chemical equilibrium state due to the characteristics of uniform mixing and rapid reaction in the top-blowing melting process. Thus, the description of the local equilibrium physical model for top-blowing smelting of electronic waste is shown in Figure 2 .

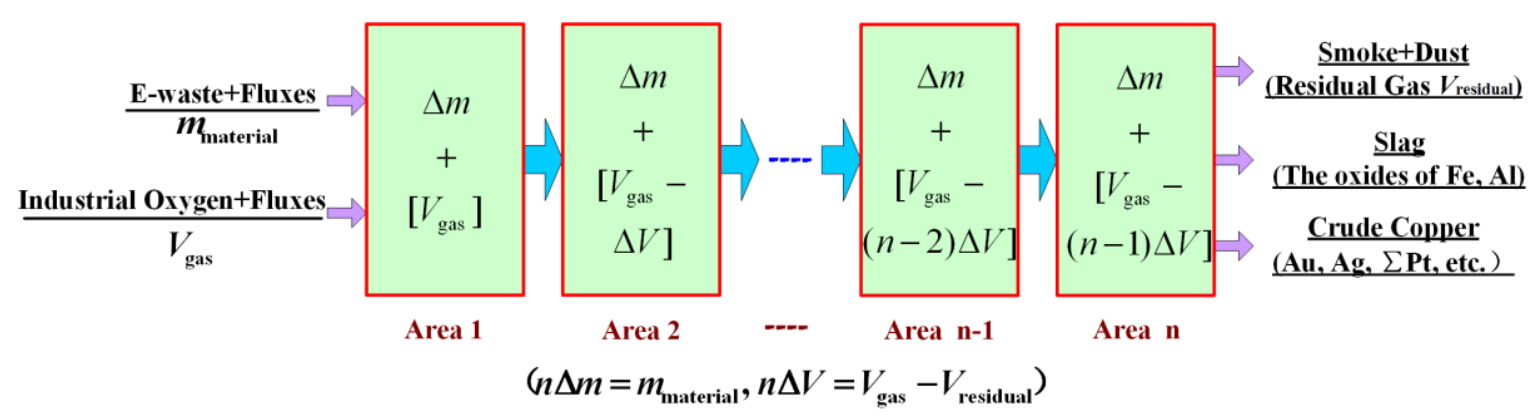

Figure 2. The description of the local equilibrium physical model for top-blowing smelting of electronic waste.

As to $m_{\text {material }}$ tons of raw materials (including electronic wastes, fluxes, and additives), assuming that the total time of the smelting takes $t$ hours and the reaction gas (industrial oxygen and air) needs $V_{g a s} \mathrm{Nm}^{3}$, then the local number $n$ can be calculated according to Equation (1):

$$
n=t \times 60 \times 60 \times 1000=3,600,000 t
$$

It will be divided into $n$ parts and gradually react with the surrounding reaction gas when the raw material with quality $m_{\text {material }}$ is put into the top-blown smelting furnace based on the local equilibrium assumption of a non-equilibrium system. That is, in the first region, the material with a mass of $\Delta m$ reacts with oxygen by a volume of $V_{g a s}$ and reaches a chemical equilibrium state, which consumes $\Delta V$ gas. Then, the materials with a mass of $\Delta m$ will react with oxygen by a volume of $\left(V_{g a s}-\Delta V\right)$ in the second area when approaching the chemical equilibrium state, and so on until the reaction takes place for $t$ hours. At this time, the last remaining material of $\Delta m$ will reach chemical equilibrium with the reaction gas by a volume of $\left[V_{g a s}-(n-1) \Delta V\right]$, and the residual gas $V_{\text {residual }}$ forms flue gas, which is discharged out of the furnace.

In the above, $\Delta m$ and $\Delta V$ can be calculated via Equation (2) and Equation (3), respectively:

$$
\begin{gathered}
\Delta m=\frac{1}{n} m_{\text {material }} \\
\Delta V=\frac{1}{n}\left(V_{\text {gas }}-V_{\text {residual }}\right)
\end{gathered}
$$

Therefore, the thermodynamic model of the top-blowing smelting process of electronic waste can be established by building a multi-phase equilibrium model of each area and using the phase transfer between the regions. 


\section{Mathematical Model and Algorithm}

\subsection{Mathematical Description}

Based on the second law of thermodynamics [31,32], for each equilibrium region in the top-blowing smelting process of electronic waste, the total Gibbs free energy can be expressed by Equation (4):

$$
G=\sum_{j=1}^{s} G_{j}^{\Theta} n_{j}+\sum_{j=s+1}^{c} \sum_{l=1}^{p} G_{l j} n_{l j}
$$

where $c$ denotes the component fraction; $p$ is the number of phases; $s$ denotes the amount of pure condensed phases; $j$ is the component of the system; $n_{j}$ denotes the mole number of the $j$ component; $G_{j}^{\Theta}$ is the standard Gibbs free energy of formation of component $j ; n_{l j}$ is the mole number of the $j$ component in the $l$ phase; $G_{l j}$ denotes the chemical potential of $j$ component in the $l$ phase.

$G_{l j}$ can be calculated by Equation (5):

$$
G_{l j}=G_{l j}^{\Theta}+R T \ln \gamma_{l j} x_{l j}
$$

where $G_{l j}^{\Theta}$ is the standard Gibbs free energy of formation of component $j$ in the $l$ phase; $\gamma_{l j}$ denotes the activity coefficient of $j$ component in the $l$ phase; $x_{l j}$ is the mole fraction of $j$ component in the $l$ phase; $R$ denotes the gas constant; $T$ is the temperature.

According to the law of mass conservation [33-35], the constraint conditions can be obtained as shown in Equation (6):

$$
b_{k}=\sum_{j=1}^{s} a_{k j} n_{j}^{c}+\sum_{j=s+1}^{c} \sum_{l=1}^{p} a_{k j} n_{l j} \quad k=1,2, \cdots m
$$

where $b_{k}$ denotes the mole number of the $k$ element; $a_{k j}$ denotes the atomic number of the $k$ element in component $j$.

In order to solve the local multi-phase equilibrium thermodynamic model consisting of Equations (4)-(6) and obtain the phase composition of each local area, the Rand algorithm [36,37] can be introduced in this work.

\subsection{Solution Algorithm of the Model}

The principle of the Rand algorithm is to expand Equation (4) of the total Gibbs free energy in the system with the second-order Taylor formula at $n^{(k)}=n_{1}^{(k)}, n_{2}^{(k)}, \cdots n_{c}^{(k)}$; simultaneously, combining with the law of conservation of mass and considering $n_{i}^{(k)}>0(i=1,2, \cdots c)$, the following equation can be obtained:

$$
\begin{aligned}
Q^{(k)}= & G^{(k)}+\sum_{j=1}^{s} \frac{\partial G^{(k)}}{\partial n_{j}^{c}}\left(N_{j}^{c}-n_{j}^{c(k)}\right)+\sum_{l=1}^{p} \sum_{j=s+1}^{c} \frac{\partial G^{(k)}}{\partial n_{j l}}\left(N_{j l}-n_{j l}^{(k)}\right) \\
& +\frac{1}{2} \sum_{j=1}^{s} \frac{\partial^{2} G^{(k)}}{\partial c_{j}^{c}}\left(N_{j}^{c}-n_{j}^{c(k)}\right)^{2} \\
& +\frac{1}{2} \sum_{l=1}^{p} \sum_{j=s+1}^{c} \sum_{k=s+1}^{c} \frac{\partial^{2} c^{(k)}}{\partial n_{j l} \partial n_{k l}}\left(N_{j l}-n_{j l}^{k}\right)\left(N_{k l}-n_{k l}^{k}\right)
\end{aligned}
$$

Then, the constraint conditions are transformed into unconstrained conditions by introducing the Lagrange factor, and the following function of $F^{(k)}$ can be constructed:

$$
F^{(k)}=Q^{(k)}+R T \sum_{k=1}^{M} \lambda_{k}\left[b_{k}-\sum_{j=1}^{s} a_{j k} N_{j}^{c}-\sum_{l=1}^{p} \sum_{j=s+1}^{c} a_{j k} N_{j l}\right]
$$


where $N$ denotes the vector of components at equilibrium, the corresponding expression is as follows:

$$
N_{l}=\sum_{j=1}^{c} N_{j l} \quad l=1, \cdots p, \quad j=1, \cdots c
$$

In addition, the necessary conditions for extreme values are:

$$
\frac{\partial F}{\partial N_{j}^{c}}=\frac{\partial F}{\partial N_{j l}}=\frac{\partial F}{\partial \lambda_{k}}=0 \quad l=1, \cdots p, \quad k=1, \cdots M
$$

Thus, in order to obtain the mole number of different components in each phase of the equilibrium system, the linear equations are solved, which are converted with nonlinear equations.

\subsection{The Calculation Process of the Mathematical Model}

Figure 3 depicts the mathematical model calculation process for the top-blowing smelting process of electronic waste. To ensure the accuracy and precision of the model calculation results, a three-layer cycle, including local iteration, composition iteration, and activity coefficient iteration [38] is adopted in this work.

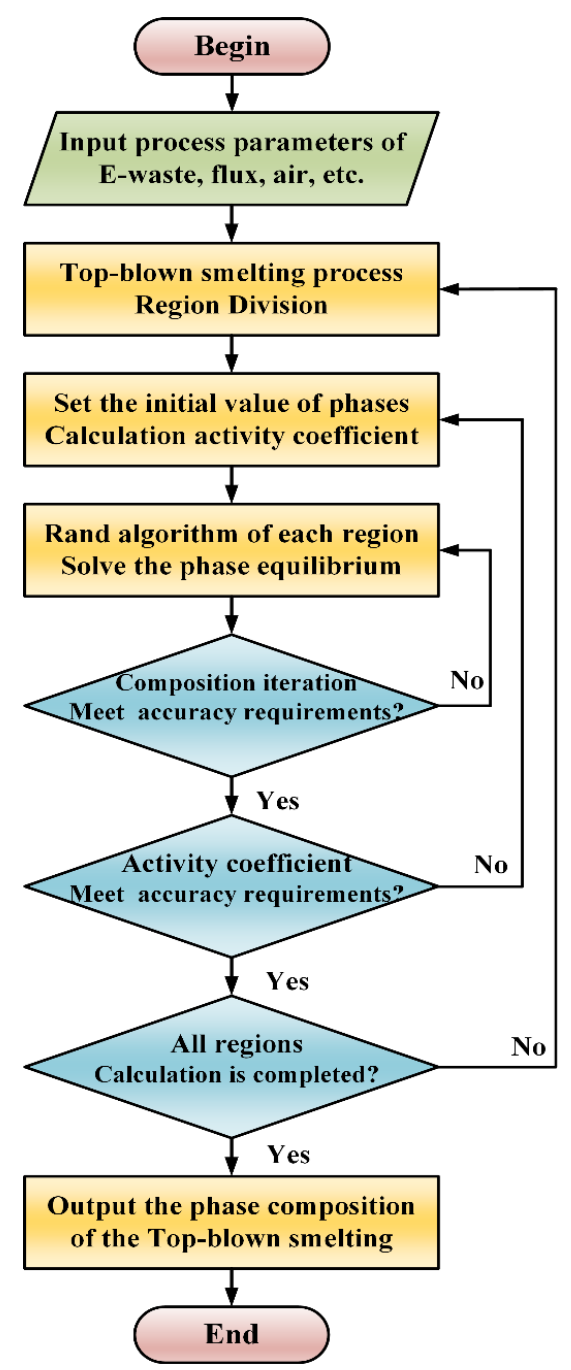

Figure 3. The mathematical model calculation process for the top-blowing smelting process of electronic waste. 


\section{Local iteration}

According to the specified smelting time, the iterative cycle calculation is performed on each local area, where the local number $n$ is calculated via Equation (1), so as to ensure that the reaction balance calculation of each local area is carried out.

\section{Composition iteration}

The initial value of each component has a great influence on the convergence of the solution process when solving the multiphase equilibrium equations via the iterative method. Especially, it can be determined by experience and trial calculations and ignore certain limitations. To ensure reliable convergence and a high convergence rate in the solution process when the input parameters change in a large range, a graded transition method to automatically adjust the initial value is proposed in this research, that is, based on the solution calculated by a group of similar system instances, it gradually approaches the current system via hierarchical adjustments and changes.

\section{Activity coefficient iteration}

The calculation process of the composition of each phase in the equilibrium system involves the activity coefficient, component, and process conditions; the activity coefficient must be iteratively calculated to ensure the correctness of the calculation result when a new composition is generated after the iteration [39].

\section{Results and Discussion}

\subsection{Thermodynamic Parameters}

The activity coefficients of each phase component required for calculation are listed in Table 1. Among them, the activity coefficients of the components are based on the reference, which is adjusted appropriately according to actual production data.

Table 1. The activity coefficient of different components [40-42].

\begin{tabular}{|c|c|c|}
\hline Components & Phase & Activity Coefficient \\
\hline $\mathrm{Cu}$ & Crude copper & 1 \\
\hline $\mathrm{Au}$ & Crude copper & $\exp (-1660 / T)$ \\
\hline $\mathrm{Ag}$ & Crude copper & $\exp (850 / T-0.070)$ \\
\hline $\mathrm{Pb}$ & Crude copper & $\exp (2670 / T-1.064)$ \\
\hline $\mathrm{Pd}$ & Crude copper & 1 \\
\hline $\mathrm{FeO}$ & Slag & $1.42 x_{\mathrm{FeO}}-0.044$ \\
\hline $\mathrm{Fe}_{3} \mathrm{O}_{4}$ & Slag & $0.69+568 x_{\mathrm{Fe}_{3} \mathrm{O}_{4}}+5.45 x_{\mathrm{SiO}_{2}}$ \\
\hline $\mathrm{SiO}_{2}$ & Slag & 2.1 \\
\hline $\mathrm{CaO}$ & Slag & 1 \\
\hline $\mathrm{PbO}$ & Slag & 1 \\
\hline $\mathrm{Cu}_{2} \mathrm{O}$ & Slag & $57.14 x_{\mathrm{Cu}_{2} \mathrm{O}}$ \\
\hline $\mathrm{Ag}_{2} \mathrm{O}$ & Slag & $4.878 \cdot \exp (1523 / T) \cdot P_{\mathrm{O} 2}^{0.0352}$ \\
\hline $\mathrm{Al}_{2} \mathrm{O}_{3}$ & Slag & 1 \\
\hline $\mathrm{B}_{2} \mathrm{O}_{3}$ & Slag & 1 \\
\hline $\mathrm{Au}$ & Slag & 50 \\
\hline $\mathrm{Ag}$ & Slag & 255 \\
\hline $\mathrm{Pd}$ & Slag & 200 \\
\hline
\end{tabular}

The Gibbs free energies of the components in various phases can be calculated according to Equation (11). Meanwhile, the Standard Gibbs energy of formation required for the calculation is listed in Table 2.

$$
\Delta G_{T}=\Delta H_{298}^{\Theta}-T \cdot \Delta S_{298}^{\Theta}+\int_{298}^{T} C p d T-T \int_{298}^{T} \frac{C p}{T} d T
$$


Table 2. The Standard formation Gibbs free energy of component [39].

\begin{tabular}{|c|c|c|c|c|c|c|c|}
\hline \multirow{2}{*}{ Component } & \multirow{2}{*}{ State } & \multirow{2}{*}{$\Delta H_{298}^{\Theta}(\mathrm{kJ} / \mathrm{mol})$} & \multirow{2}{*}{$\Delta S_{298}^{\Theta}(\mathrm{J} / \mathrm{Kmol})$} & \multicolumn{4}{|c|}{$C p=a+b \times 10^{-3} T+c \times 10^{5} T^{-2}+d \times 10^{-6} T^{2}(\mathrm{~J} / \mathrm{kgK})$} \\
\hline & & & & $a$ & $b$ & $c$ & $d$ \\
\hline $\mathrm{Cu}$ & 1 & 8.028 & 34.236 & 32.845 & 0.000 & 0.000 & 0.000 \\
\hline $\mathrm{Au}$ & 1 & 0.000 & 47.489 & 23.326 & 6.053 & 0.237 & -1.181 \\
\hline $\mathrm{Ag}$ & 1 & 0.000 & 42.678 & 24.347 & 2.544 & 0.025 & 2.895 \\
\hline $\mathrm{Pb}$ & 1 & 3.873 & 70.506 & 32.490 & -3.088 & 0.000 & 0.000 \\
\hline $\mathrm{Pd}$ & 1 & 0.000 & 37.824 & 32.192 & -14.188 & -3.368 & 11.480 \\
\hline $\mathrm{FeO}$ & 1 & -256.323 & 52.148 & 52.148 & 0.000 & 0.000 & 0.000 \\
\hline $\mathrm{Fe}_{3} \mathrm{O}_{4}$ & 1 & -993.310 & 198.380 & 213.384 & 0.000 & 0.000 & 0.000 \\
\hline $\mathrm{SiO}_{2}$ & 1 & -927.526 & 9.309 & 85.772 & 0.000 & 0.000 & 0.000 \\
\hline $\mathrm{CaO}$ & 1 & -572.895 & 40.979 & 62.760 & 0.000 & 0.000 & 0.000 \\
\hline $\mathrm{PbO}$ & 1 & -202.244 & 73.377 & 73.377 & 0.000 & 0.000 & 0.000 \\
\hline $\mathrm{Cu}_{2} \mathrm{O}$ & 1 & -130.221 & 96.399 & 99.914 & 0.000 & 0.000 & 0.000 \\
\hline $\mathrm{Ag}_{2} \mathrm{O}$ & 1 & -31.131 & 121.003 & 59.433 & 40.341 & -4.812 & -2.390 \\
\hline $\mathrm{Al}_{2} \mathrm{O}_{3}$ & 1 & -1675.732 & 50.950 & 9.777 & 294.732 & -2.485 & -198.179 \\
\hline $\mathrm{B}_{2} \mathrm{O}_{3}$ & 1 & -1273.530 & 59.971 & 64.160 & 64.598 & -18.366 & 0.033 \\
\hline $\mathrm{CO}_{2}$ & $\mathrm{~g}$ & -393.515 & 213.774 & 22.227 & 56.202 & 0.105 & -22.519 \\
\hline $\mathrm{O}_{2}$ & $\mathrm{~g}$ & 0.000 & 205.154 & 22.060 & 20.887 & 1.621 & -8.207 \\
\hline $\mathrm{N}_{2}$ & $\mathrm{~g}$ & 0.000 & 191.615 & 23.529 & 12.116 & 1.210 & -3.076 \\
\hline $\mathrm{H}_{2} \mathrm{O}$ & $\mathrm{g}$ & -285.837 & 69.952 & 186.889 & -464.258 & -19.565 & 548.644 \\
\hline $\mathrm{Pb}$ & $\mathrm{g}$ & 0.000 & 64.802 & 26.354 & -6.154 & -0.157 & 25.977 \\
\hline $\mathrm{PbO}$ & $\mathrm{g}$ & 70.300 & 240.042 & 33.413 & 6.852 & -2.395 & -2.940 \\
\hline $\mathrm{HCl}$ & $\mathrm{g}$ & -92.314 & 186.900 & 29.151 & -0.365 & 0.000 & 1.099 \\
\hline $\mathrm{Cl}_{2}$ & g & 0.000 & 223.084 & 23.274 & 51.224 & 0.144 & -53.560 \\
\hline $\mathrm{Br}_{2}$ & g & 0.000 & 152.214 & -39.004 & 368.864 & 28.711 & -310.331 \\
\hline $\mathrm{HBr}$ & $\mathrm{g}$ & -36.291 & 196.702 & 29.102 & 0.053 & 0.000 & 0.231 \\
\hline
\end{tabular}

\subsection{Process Parameters}

\subsubsection{Material and Methods}

The raw material of the cutout of copper-clad laminate used in the present work was provided by a non-ferrous smeltery from Jiangxi Province in China. The chemical compositions of the materials were measured by $\mathrm{X}$-ray fluorescence (XRF), as shown in Table 3. It can be seen that the mass fraction of $\mathrm{B}_{2} \mathrm{O}_{3}$ in the scrap copper clad laminate is up to $16.89 \mathrm{wt} \%$ compared with the copper concentrate, but the Fe content and the ratio of $\mathrm{Fe} / \mathrm{SiO}_{2}$ are only $0.19 \mathrm{wt} \%$ and 0.011 , respectively, which is difficult to meet the requirements of general slag type, resulting in the inability to obtain slag with suitable melting point and viscosity. In addition, the amount of organic matter in copper-clad laminate is approximately $23.9 \mathrm{wt} \%$.

Table 3. Chemical compositions of the cutout of copper-clad laminate.

\begin{tabular}{|c|c|c|c|c|c|c|c|c|c|c|c|}
\hline Contents & $\mathrm{Cu}$ & $\mathrm{Au}(\mathrm{g} / \mathrm{t})$ & $\operatorname{Ag}(g / t)$ & $P d$ & $\mathrm{~Pb}$ & $\mathrm{Fe}$ & $\mathrm{SiO}_{2}$ & $\mathrm{CaO}$ & $\mathrm{Al}_{2} \mathrm{O}_{3}$ & $\mathrm{~B}_{2} \mathrm{O}_{3}$ & $\mathrm{H}_{2} \mathrm{O}$ \\
\hline$(w t \%)$ & 19.43 & 0.20 & 0.50 & 0.48 & 0.038 & 0.19 & 16.91 & 9.59 & 6.84 & 16.89 & 5.00 \\
\hline Organic & \multicolumn{2}{|c|}{$\mathrm{C}_{2} \mathrm{H}_{3} \mathrm{Cl}$} & $\mathrm{C}_{2} \mathrm{H}_{4}$ & \multicolumn{2}{|c|}{$\mathrm{CH}_{3} \mathrm{NO}_{2}$} & $\mathrm{C}_{7} \mathrm{H}_{8} \mathrm{O}_{2}$ & \multicolumn{2}{|c|}{$\mathrm{C}_{12} \mathrm{H}_{6} \mathrm{Cl}_{4}$} & $\mathrm{C}_{12} \mathrm{H}_{8} \mathrm{Br}_{2}$ & \multicolumn{2}{|c|}{$\mathrm{C}_{15} \mathrm{H}_{16} \mathrm{O}_{2}$} \\
\hline (wt \%) & \multicolumn{2}{|c|}{5.00} & 10.00 & \multicolumn{2}{|c|}{3.00} & 7.00 & \multicolumn{2}{|c|}{3.00} & 12.00 & \multicolumn{2}{|c|}{60.00} \\
\hline
\end{tabular}

Moreover, the viscosity and temperature of the smelting slag of electronic waste decrease rapidly with the increase in $\mathrm{B}_{2} \mathrm{O}_{3}$ and the ratio of $\mathrm{CaO} / \mathrm{SiO}_{2}$, while the viscosity increases and the temperature increases first and then decreases with the rise in $\mathrm{FeO}$, according to the author's previous work [43].

Therefore, to achieve a slag state with good viscosity and melting point, it is necessary to appropriately increase the amounts of $\mathrm{Fe}$ and $\mathrm{CaO}$ in the slag and avoid the contamination of impurities. In this study, the limestone with $86 \mathrm{wt} \% \mathrm{CaCO}_{3}$ and iron powder with 
$95 \mathrm{wt} \% \mathrm{Fe}$, respectively, are added as the additive to the high-temperature melt, where the amount added of the fluxes are determined based on the types of slag.

Generally, the high-temperature quench sampling technology is used to collect samples from industrial smelting furnaces. Practice indicates that the important parameters including phase component and chemical composition of high-temperature melt can be obtained without affecting normal production, which provides a reliable method for sampling from high-temperature furnaces in the electronic waste industry.

According to the industrial production practice, the high-temperature melt can be taken out from the outlets of slag and crude copper by a steel spoon during the stable NRT smelting, which is a typical top-blown smelting of electronic waste. After being quenched with water, the reaction products can be collected at different times with the interval of $30 \mathrm{~min}$, and the sampling time is repeated three times to eliminate the systematic error.

The chemical compositions of the above samples were determined by the X-ray Fluorescence Spectrometry (XRF, AXIOS-MAX, Almelo, The Netherlands) and directreading inductively coupled plasma-optical emission spectrometer (ICP-OES, IRIS Intrepid II XSP, Thermo Fisher Scientific Co., Waltham, MA, USA), respectively.

\subsubsection{Conditional Control}

Based on the industrial production practice of top-blown smelting of electronic waste, the process and control parameters are discussed in detail. In this work, the processing capacity of the scrap copper-clad laminate is up to $3.13 \mathrm{t} / \mathrm{h}$. After smelting for $4 \mathrm{~h}$ with conditions of oxygen grade of $21 \%$ and total air of $6000 \mathrm{Nm}^{3} / \mathrm{h}$, the contents of $\mathrm{CaO}$ and $\mathrm{FeO}$ in the slag were found to be $31 \%$ and $3 \%$, respectively. Meanwhile, the corresponding dust rate and air leakage rate are controlled at $5 \%$ and $10 \%$, respectively. More importantly, the heat balance parameters are fixed as follows: the area of the furnace wall of $119 \mathrm{~m}^{2}$, the lining thickness of $0.4 \mathrm{~m}$, the ambient temperature of $25^{\circ} \mathrm{C}$, the convective heat-transfer coefficient of $18 \mathrm{~W} /\left(\mathrm{m}^{2} \cdot \mathrm{K}\right)$, and the coefficient of blackness with 0.8 . The parameters of crude copper, slag, off-gas, dust, and flue gas are automatically calculated based on the balance of heat.

\subsection{The Foundation of a Simulation System}

After establishing the mathematical model of local equilibrium and thermodynamic parameters in top-blown smelting of electronic waste, the corresponding thermodynamic digital simulation system was developed based on the calculation of metallurgical process and an online control platform MetCal Desk (v7.00, MetCal, Ganzhou, China) [44], as illustrated in Figure 4. The simulation system links the relevant information of each metallurgical unit from top to bottom in an orderly manner and can effectively calculate the material balance and thermal balance of the electronic waste, which provides an effective method for investigating the distribution behavior of elements during the top-blowing smelting process.

\subsection{Test Case}

The calculation and verification of the simulation system were carried out based on industrial production. On this basis, the phase composition, component, feed rate, and other parameters of the optimization model can be adjusted to improve the consistency with the production practice.

\subsubsection{Material Balance of Input-Output}

Table 4 shows the input-output material balance in the NRT smelting of electronic waste combined with the production practice of the top-blown smelting industry. After inputting the scrap copper-clad laminate of $3130 \mathrm{~kg} / \mathrm{h}$, the iron powder of $67.51 \mathrm{~kg} / \mathrm{h}$, and the limestone of $740.3 \mathrm{~kg} / \mathrm{h}$, it produces $515.6 \mathrm{~kg} / \mathrm{h}$ of the crude copper, $2058.51 \mathrm{~kg} / \mathrm{h}$ of the slag, $8926.77 \mathrm{~kg} / \mathrm{h}$ of the off-gas, and $159.88 \mathrm{~kg} / \mathrm{h}$ of the dust, respectively. Significantly, both the temperature of off-gas and dust can be up to $1317^{\circ} \mathrm{C}$. 


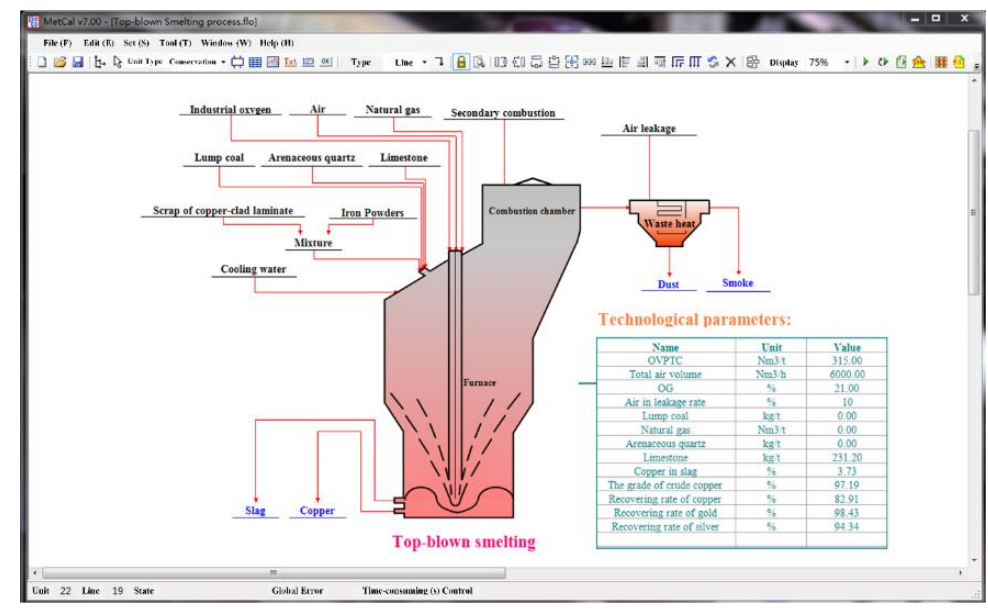

Figure 4. The interface of the thermodynamic simulation system for the top-blown smelting process of electronic waste.

Table 4. The input-output material balance in the NRT smelting of electronic waste.

\begin{tabular}{|c|c|c|c|c|c|c|c|c|}
\hline \multirow{2}{*}{ No. } & \multicolumn{4}{|c|}{ Input } & \multicolumn{4}{|c|}{ Output } \\
\hline & Phase & ${ }^{\circ} \mathrm{C}$ & $\mathrm{kg} / \mathrm{h}$ & $\mathrm{Nm}^{3} / \mathrm{h}$ & Phase & ${ }^{\circ} \mathrm{C}$ & $\mathrm{kg} / \mathrm{h}$ & $\mathrm{Nm}^{3} / \mathrm{h}$ \\
\hline 1 & Scrap of copper-clad laminate & 25 & 3130.00 & & Crude copper & 1250 & 515.60 & \\
\hline 2 & Iron powder & 25 & 67.51 & & Slag & 1280 & 2058.51 & \\
\hline 3 & Limestone & 25 & 740.30 & & Off-gas & 1317 & 8926.77 & 6730.56 \\
\hline 4 & Arenaceous quartz & 25 & 0.00 & & Dust & 1317 & 159.88 & \\
\hline 5 & Industrial oxygen & 25 & 0.00 & 0.00 & & & & \\
\hline \multirow[t]{2}{*}{6} & Air & 25 & 7722.94 & 6000.00 & & & & \\
\hline & Total & & $11,660.75$ & 6000.00 & Total & & $11,660.75$ & 6730.56 \\
\hline
\end{tabular}

\subsubsection{The Contents of Products}

After the NRT smelting of electronic waste according to the thermodynamic digital simulation system, the element composition (XRF) of products was analyzed in detail, as shown in Table 5. It can be found that the elements of $\mathrm{Cu}, \mathrm{Au}, \mathrm{Ag}$, and Pd mainly existed in the crude copper, simultaneously, $16.98 \mathrm{wt} \%$ of $\mathrm{Cu}$ entered into the dust. On the other hand, the slag phase consisted chiefly of $\mathrm{FeO}, \mathrm{SiO}_{2}, \mathrm{CaO}, \mathrm{Al}_{2} \mathrm{O}_{3}$, and $\mathrm{B}_{2} \mathrm{O}_{3}$, with the corresponding contents of $3 \mathrm{wt} \%, 25.46 \mathrm{wt} \%, 31 \mathrm{wt} \%, 9.66 \mathrm{wt} \%$, and $23.87 \mathrm{wt} \%$, respectively. Moreover, the off-gas was mainly composed of $\mathrm{CO}_{2}$ and $\mathrm{N}_{2}$, and a small amount of $\mathrm{H}_{2} \mathrm{O}$.

Table 5. The contents of products in the NRT smelting of electronic waste.

\begin{tabular}{|c|c|c|c|c|c|c|c|c|c|}
\hline \multirow{2}{*}{ No. } & \multicolumn{2}{|c|}{ Crude Copper } & \multicolumn{2}{|c|}{ Slag } & \multicolumn{3}{|c|}{ Off-Gas } & \multicolumn{2}{|c|}{ Dust } \\
\hline & Phase & $\mathbf{w t} \%$ & Phase & $w t \%$ & Phase & $w t \%$ & $\mathrm{v} \%$ & Phase & $w t \%$ \\
\hline 1 & $\mathrm{Cu}$ & 97.18 & $\mathrm{FeO}$ & 3.00 & $\mathrm{CO}_{2}$ & 25.49 & 17.22 & $\mathrm{Cu}$ & 16.98 \\
\hline 2 & $\mathrm{Au}$ & $1.14 \times 10^{-4}$ & $\mathrm{SiO}_{2}$ & 25.46 & $\mathrm{O}_{2}$ & 0.05 & 0.05 & $\mathrm{~Pb}$ & 0.05 \\
\hline 3 & $\mathrm{Ag}$ & $2.73 \times 10^{-4}$ & $\mathrm{Cu}_{2} \mathrm{O}$ & 4.37 & $\mathrm{~N}_{2}$ & 66.42 & 70.49 & $\mathrm{Fe}$ & 13.21 \\
\hline 4 & $\mathrm{~Pb}$ & $4.51 \times 10^{-5}$ & $\mathrm{CaO}$ & 31.00 & $\mathrm{H}_{2} \mathrm{O}$ & 7.11 & 11.74 & $\mathrm{SiO}_{2}$ & 23.49 \\
\hline 5 & $\mathrm{Pd}$ & 2.82 & $\mathrm{Fe}_{3} \mathrm{O}_{4}$ & 0.16 & $\mathrm{~Pb}$ & 0.00 & 0.00 & $\mathrm{CaO}$ & 13.32 \\
\hline 6 & - & - & $\mathrm{PbO}$ & 0.06 & $\mathrm{PbO}$ & 0.00 & 0.00 & $\mathrm{Al}_{2} \mathrm{O}_{3}$ & 9.49 \\
\hline 7 & - & - & $\mathrm{Au}$ & 0.00 & $\mathrm{HCl}$ & 0.38 & 0.31 & $\mathrm{~B}_{2} \mathrm{O}_{3}$ & 23.46 \\
\hline 8 & - & - & $\mathrm{Ag}$ & 0.00 & $\mathrm{Cl}_{2}$ & 0.00 & 0.00 & - & - \\
\hline 9 & - & - & $\mathrm{Pd}$ & 0.02 & $\mathrm{Br}_{2}$ & 0.01 & 0.00 & - & - \\
\hline 10 & - & - & $\mathrm{Ag}_{2} \mathrm{O}$ & 0.00 & $\mathrm{HBr}$ & 0.53 & 0.19 & - & - \\
\hline 11 & - & - & $\mathrm{Al}_{2} \mathrm{O}_{3}$ & 9.66 & - & - & - & - & - \\
\hline 12 & - & - & $\mathrm{B}_{2} \mathrm{O}_{3}$ & 23.87 & - & - & - & - & - \\
\hline \multirow[t]{2}{*}{13} & - & - & Other & 2.40 & - & - & - & - & - \\
\hline & Total & 100.00 & Total & 100.00 & Total & 100.00 & 100.00 & Total & 100.00 \\
\hline
\end{tabular}




\subsubsection{Heat Balance of Input-Output}

The heat balance of input-output during the NRT smelting of electronic waste is also an important parameter based on the simulation system, as illustrated in Table 6. It can be noted that all heat income was provided by the chemical heat with the amount of heat $21,689.46 \mathrm{MJ} / \mathrm{h}$. On the contrary, the physical heat played an important role in terms of the heat expenditure, which occupied about 18,348.34 MJ/h of the heat. At the same time, the exchanged heat and natural heat dissipation were also part of the heat output, in which the quantities of heat were 1044.34 MJ/h and $2296.78 \mathrm{MJ} / \mathrm{h}$, respectively.

Table 6. Heat balance of input-output in NRT smelting of electronic waste.

\begin{tabular}{|c|c|c|c|c|c|c|c|c|c|}
\hline \multirow{2}{*}{ No. } & \multicolumn{5}{|c|}{ Heat Income } & \multicolumn{4}{|c|}{ Heat Output } \\
\hline & Type & Materials & $T\left({ }^{\circ} \mathrm{C}\right)$ & $\mathrm{MJ} / \mathrm{h}$ & $\%$ & Materials & $T\left({ }^{\circ} \mathrm{C}\right)$ & $\mathrm{MJ} / \mathrm{h}$ & $\%$ \\
\hline \multirow{7}{*}{1} & \multirow{7}{*}{ Physical heat } & $\begin{array}{l}\text { Scrap of copper-clad } \\
\text { laminate }\end{array}$ & 25 & 0.00 & 0.00 & Copper & 1250 & 322.09 & 1.49 \\
\hline & & Iron powder & 25 & 0.00 & 0.00 & Slag & 1280 & 3605.05 & 16.62 \\
\hline & & Limestone & 25 & 0.00 & 0.00 & Off-gas & 1317 & $14,183.16$ & 65.39 \\
\hline & & Arenaceous quartz & 25 & 0.00 & 0.00 & Dust & 1317 & 238.04 & 1.10 \\
\hline & & Industrial oxygen & 25 & 0.00 & 0.00 & & & & \\
\hline & & Air & 25 & 0.00 & 0.00 & & & & \\
\hline & & Total & & 0.00 & 0.00 & Total & & $18,348.34$ & 84.60 \\
\hline 2 & Chemical heat & & 25 & $21,689.46$ & 100.00 & & 25 & & \\
\hline 3 & Exchanged heat & Top cooling water & 25 & & & Top cooling water & 30 & 1044.34 & 4.81 \\
\hline 4 & Natural Cooling & & & & & & 208 & 2296.78 & 10.59 \\
\hline & Total & & & $21,689.46$ & 100.00 & & & $21,689.46$ & 100.00 \\
\hline
\end{tabular}

\subsubsection{Comparisons with Industrial Results}

To verify the accuracy of the mathematical model of local equilibrium in the topblown smelting process of electronic waste, the simulated results were compared with the industrial data based on the production practice of the NRT smelting, as shown in Figure 5. It can be found that the predictive values of the elements in the crude copper coincided with the industrial data. Similarly, the simulated results of oxides in the slag were in good agreement with the industrial values. In addition, some elements and oxides from the industrial data were slightly larger than the simulated results in terms of mechanical inclusion, as depicted in Figure 5b,d. Therefore, the simulation system established by the local equilibrium mathematical model can provide theoretical guidance for the industrial production practice for the top-blowing smelting process of electronic waste.

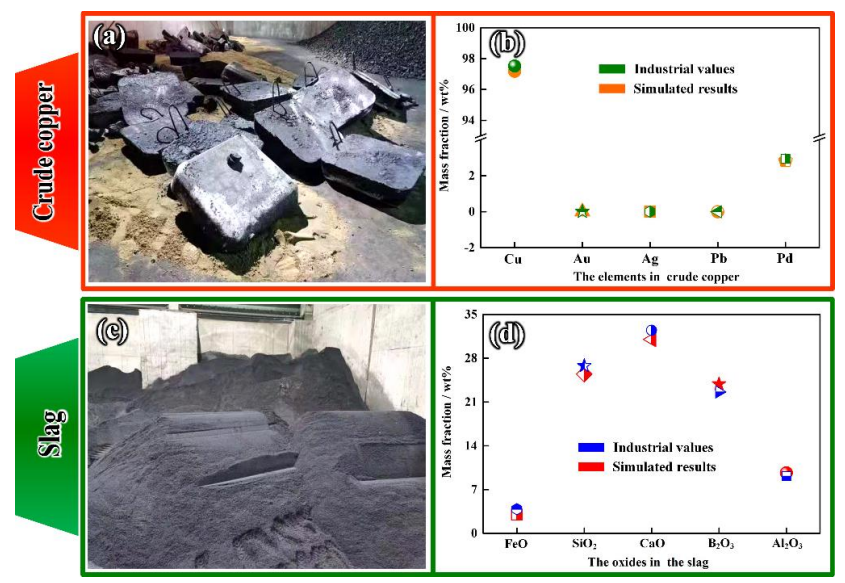

Figure 5. The comparisons between industrial values and simulated results: (a) photograph of the crude copper produced by the enterprise; (b) comparison of the elements in crude copper; (c) picture of the slag produced by the same enterprise; (d) comparison of the oxides in the slag. 


\section{Conclusions}

In summary, a mathematical model of local equilibrium for the top-blowing smelting process of electronic waste was established based on the non-equilibrium multiphase reaction system. Simultaneously, the corresponding thermodynamic digital simulation system was developed according to the calculation of metallurgical process and online control platform (MetCal Desk). The comparisons between the industrial values and simulated results of the elements in the crude copper and oxides in the slag were respectively validated in this study. Therefore, it provides an effective and innovative method for the study of elements distribution behavior in the top-blowing smelting process of electronic waste, which also can provide theoretical guidance for the industrial production practice.

Author Contributions: Conceptualization, J.W. and X.W.; methodology, J.W. and X.W.; software, J.W.; validation, X.W., J.W. and H.W.; formal analysis, X.W. and H.W.; investigation, X.W. and H.W.; data curation, J.W. and X.W.; writing-original draft preparation, X.W.; writing-review and editing, X.W., J.W. and H.W.; supervision, J.W. All authors have read and agreed to the published version of the manuscript.

Funding: This research was funded by the National Natural Science Foundation of China (No. 51764018 and No. 51564018), the Jiangxi Provincial Key Laboratory of Flash Green Development and Recycling (20193BCD40019), and the Program of Qingjiang Excellent Young Talents, Jiangxi University of Science and Technology.

Data Availability Statement: Data presented in this article are available at request from the corresponding author.

Conflicts of Interest: The authors declare no conflict of interest.

\section{References}

1. Cayumil, R.; Khanna, R.; Rajarao, R.; Mukherjee, P.S.; Sahajwalla, V. Concentration of precious metals during their recovery from electronic waste. Waste Manag. 2016, 57, 121-130. [CrossRef]

2. Kumari, A.; Jha, M.K.; Lee, J.; Singh, R.P. Clean process for recovery of metals and recycling of acid from the leach liquor of PCBs. J. Clean Prod. 2016, 112, 4826-4834. [CrossRef]

3. Bidini, G.; Fantozzi, F.; Bartocci, P.; D’Alessandro, B.; D’Amico, M.; Laranci, P.; Scozza, E.; Zagaroli, M. Recovery of precious metals from scrap printed circuit boards through pyrolysis. J. Anal. Appl. Pyrol. 2015, 111, 140-147. [CrossRef]

4. Remeteiová, D.; Ružičková, S.; Mičková, V.; Laubertová, M.; Slezáková, R. Evaluation of US EPA Method 3052 Microwave Acid Digestion for Quantification of Majority Metals in Waste Printed Circuit Boards. Metals 2020, 10, 1511. [CrossRef]

5. Burke, M. The gadget scrap heap. Chem. World 2007, 4, 45-48.

6. Cucchiella, F.; D'Adamo, I.; Koh, S.C.L.; Rosa, P. Recycling of WEEEs: An economic assessment of present and future e-waste streams. Renew. Sustain. Energy Rev. 2015, 51, 263-272. [CrossRef]

7. Brodersen, K.; Tartler, D.; Danzer, B. Scrap of electronics a challenge to recycling activities. In Proceedings of the 1994 IEEE International Symposium on Electronics and the Environment, San Francisco, CA, USA, 2-4 May 1994; pp. $174-176$.

8. Duan, H.B.; Huang, Q.F.; Wang, Q.; Zhou, B.Y.; Li, J.H. Hazardous waste generation and management in China: A review. J. Hazard. Mater. 2008, 158, 221-227. [CrossRef] [PubMed]

9. Kwapisiński, P.; Wołczyński, W.; Bydałek, A.W.; Schlafka, P.; Bydałek, A. Analysis of separation mechanism of the metallic phase of slag in the Direct-To-Blister Process. Arch. Metall. Mater. 2015, 60, 2347-2353.

10. Meng, L.; Zhong, Y.W.; Guo, L.; Wang, Z.; Chen, K.Y.; Guo, Z.C. High-temperature centrifugal separation of Cu from waste printed circuit boards. J. Clean. Prod. 2018, 199, 831-839. [CrossRef]

11. Meng, L.; Wang, Z.; Zhong, Y.W.; Guo, L.; Gao, J.T.; Chen, K.Y.; Cheng, H.J.; Guo, Z.C. Supergravity separation for recovering metals from waste printed circuit boards. Chem. Eng. J. 2017, 326, 540-550. [CrossRef]

12. Tabassum, S.; Ghosh, A.; Meshram, P.; van Hullebusch, E.D. Microbial Processing of Waste Shredded PCBs for Copper Extraction Cum Separation-Comparing the Efficacy of Bacterial and Fungal Leaching Kinetics and Yields. Metals 2021, 11, 317.

13. Argumedo-Delira, R.; Díaz-Martínez, M.E.; Gómez-Martínez, M.J. Microorganisms and plants in the recovery of metals from the printed circuit boards of computers and cell phones: A mini review. Metals 2020, 10, 1120. [CrossRef]

14. Cui, J.; Zhang, L. Metallurgical recovery of metals from electronic waste: A review. J. Hazard. Mater. 2008, 158, 228-256. [CrossRef]

15. Zhang, H.; Wang, Y.; He, Y.; Xu, S.; Hu, B.; Cao, H.; Zhou, J.; Zheng, G. Efficient and safe disposition of arsenic by incorporation in smelting slag through copper flash smelting process. Miner. Eng. 2021, 160, 106661. [CrossRef]

16. Xu, B.; Yang, Y.; Li, Q.; Yin, W.; Jiang, T.; Li, G. Thiosulfate leaching of Au, Ag and Pd from a high Sn, Pb and $\mathrm{Sb}$ bearing decopperized anode slime. Hydrometallurgy 2016, 164, 278-287. [CrossRef]

17. Amer, A.M. Processing of copper anodic-slimes for extraction of valuable metals. Waste Manag. 2003, 23, 763-770. [CrossRef] 
18. Xia, Z. Simulation Research on Fluid Flow Behavior of Sirosmelt; Kunming University of Science and Technology: Kunming, China, 2015.

19. Chen, Z.; Wang, Y.X.; Zhou, J.; Liu, A.M.; Mei, C. Simulation Study of Intensified Flash Smelting Process, Copper 2010; DGBM: Hamburg, Germany, 2010; pp. 1313-1323.

20. Kang, H.Y.; Schoenung, J.M. Electronic waste recycling: A review of US infrastructure and technology options. Resour. Conserv. Recy. 2005, 45, 368-400. [CrossRef]

21. Wołczyński, W.; Bydałek, A.W.; Tarasek, A.; Sypien, A. Copper droplets agglomeration/coagulation in the conditions similar to industrial ones. Arch. Metall. Mater. 2017, 62, 289-296. [CrossRef]

22. Wang, J.L. Metallurgical calculation and production practice of oxygen-enriched side-blown bath smelting process. China Nonferrous Metall. 2012, 41, 6-9.

23. Xu, X.; Su, Y.; Huang, H. Simulation calculation of double side blow furnace's process based on Metcal. Nonferrous Met. Extr. Metall. 2016, 6, 31-34.

24. Zhang, H.L.; Zhou, C.Q.; Bing, W.U.; Chen, Y.M. Numerical simulation of multiphase flow in a Vanyukov furnace. J. S. Afr. I Min. Metall. 2015, 115, 457-463. [CrossRef]

25. Li, M.Z.; Zhou, J.M.; Tong, C.R.; Zhang, W.H.; Chen, Z.; Wang, J.L. Thermodynamic Modeling and Optimization of the Copper Flash Converting Process Using the Equilibrium Constant Method. Metall. Mater. Trans. B. 2018, 49, 1794-1807. [CrossRef]

26. Li, M.Z.; Tong, C.R.; Huang, J.; Wang, J.L. Simulated Calculation of Overall Process Flow of Copper Bottom Blowing Smelting. Chin. J. Process. Eng. 2016, 16, 1028-1037.

27. Wołczyński, W. Pattern Selection in the Eutectic Growth-Thermodynamic Interpretation. Arch. Metall. Mater. 2020, 65, 653-666.

28. Koshikawa, T.; Gandin, C.A.; Bellet, M.; Yamamura, H.; Bobadilla, M. Computation of phase transformation paths in steels by a combination of the partial- and para-equilibrium thermodynamic approximations. ISIJ Int. 2014, 54, 1274-1282. [CrossRef]

29. Zhang, H.W.; Liu, Q.; Shibata, H.; Wang, Q.; Jönsson, P.; He, J.C.; Nakajima, K. Partial Equilibrium Prediction of Solidification and Carbide Precipitation in Ti-added High Cr Cast Irons. ISIJ Int. 2014, 54, 374-383. [CrossRef]

30. Wang, J.L.; Zhang, C.F.; Zhang, W.H. Formation thermodynamic of Fe3O4 in reaction shaft of flash smelting furnace. J. Cent. South Univ. (Sci. Technol.) 2013, 44, 4787-4792.

31. Lieb, E.H.; Yngvason, J. The physics and mathematics of the second law of thermodynamics. Phys. Rep. 1999, 310, 1-96. [CrossRef]

32. Teh, Y.S.; Rangaiah, G.P. A study of equation-solving and Gibbs free energy minimization methods for phase equilibrium calculations. Chem. Eng. Res. Des. 2002, 80, 745-759. [CrossRef]

33. Kambe, T. New perspectives on mass conservation law and waves in fluid mechanics. Fluid. Dyn. Res. 2020, 52, 031401. [CrossRef]

34. Mohebujjaman, M.; Rebholz, L.G.; Xie, X.; Iliescu, T. Energy balance and mass conservation in reduced order models of fluid flows. J. Comput. Phys. 2017, 346, 262-277. [CrossRef]

35. Chai, Z.H.; Sun, D.K.; Wang, H.L.; Shi, B.C. A comparative study of local and nonlocal Allen-Cahn equations with mass conservation. Int. J. Heat Mass. Tran. 2018, 122, 631-642. [CrossRef]

36. Wang, J.L. Slag Activity Research and Numerical Simulation of Heavy Metal Smelting Process with Short Flow. Ph.D. Thesis, Central South University, Changsha, China, 2009.

37. Ji, K.Y.; Wang, Z.; Zhou, Y.; Liang, Y.B. Improved zeroth-order variance reduced algorithms and analysis for nonconvex optimization. In Proceedings of the International Conference on Machine Learning (PMLR), Long Beach, CA, USA, 9-15 June 2019; pp. 3100-3109.

38. Bloom, S.L.; Ésik, Z. Iteration Theories; Springer: Berlin/Heidelberg, Germany, 1993; pp. 159-213.

39. Ye, D.; Hu, J. Handbook of Inorganic Thermodynamics; Metallurgical Industry Press: Beijing, China, 2002.

40. Nagamori, M.; Chaubal, P.C. Thermodynamics of copper matte converting: Part III. Steady-state volatilization of Au, Ag, Pb, Zn, $\mathrm{Ni}, \mathrm{Se}, \mathrm{Te}, \mathrm{Bi}, \mathrm{Sb}$, and As from slag, matte, and metallic copper. J. Electron. Mater. 1991, 20, 319-329. [CrossRef]

41. Tan, P.; Neuschütz, D. A thermodynamic model of nickel smelting and direct high-grade nickel matte smelting processes: Part I. Model development and validation. Metall. Mater. Trans. B. 2001, 32, 341-351. [CrossRef]

42. Tan, P.F.; Zhang, C.F. Computer model of copper smelting process and distribution behaviors of accessory elements. J. Cent. South Univ. 1997, 4, 36-41. [CrossRef]

43. Wang, J.; Wang, L. Research of melting temperature of the smelting slag of copper clad laminate scrap. Non-Ferr. Met. Sci. Eng. 2020, 11, 46-50.

44. Li, M.Z.; Tong, C.R.; Huang, J.D.; Li, J.; Wang, J.L. Simulated calculation of overall process flow of copper flash smelting and converting based on Metcal. Non-Ferr. Met. Sci. Eng. 2016, 6, 31-34. 